\title{
IMPACT OF E-SERVICE QUALITY OF ONLINE SHOPPING ON CUSTOMER LOYALTY INTENTION: A CASE OF PUTHUR GRAMAPANCHAYATH, THRISSUR
}

\author{
Greeshma K S \\ Assistant Professor (Guest) \\ College of Co-operation Banking \& Management \\ Kerala Agricultural University, Thrissur, Kerala, India
}

\begin{abstract}
In this modern era of global competition two factors such as customer expectation and customer satisfaction vitally contributes towards the success of any industry. Now these days' people are using e-commerce more widely for shopping. And the key determinants of success or failure are not merely web site presence and low price but also include e-service quality. In case of a failure in meeting the expectation of customer will affect the overall growth and survival of the business in the market to withstand the global competition and market dynamism, it is essential for the business to scrutinize all the factors which leads to customer satisfaction in order to enable a business to point out the areas of weakness. This study is a descriptive in nature has been carried out in Puthur Garmapanchayath with a sample of 150 people selected on the basis of convenience sampling method. The present study finds that the efficiency provides more service quality in online shopping and responsiveness provide a least service quality. Although the study concluded that e-service quality dimensions and customer satisfaction are the key drivers of customer loyalty.
\end{abstract}

Keywords: E-commerce, E-service quality, Customer satisfaction, Customer loyalty.

\section{INTRODUCTION}

Because of the accelerated global advancement in electronic commerce (e-commerce) businesses are attempting to gain a competitive advantage by using e-commerce to interact with customers. Customer is supposed to be the king of market. In an e-commerce setting, companies can use their internet to deliver products and services to their customers and they can have mutual relationships with customers that they have never seen, met, or spoken to. Businesses/ entrepreneurs with the most experience and accomplishment in using ecommerce are beginning to realize that the key determinants of success or failure are not only web site presence and low price but also include eservice quality. Service quality and customer satisfaction go hand in hand and quality in service delivery is the key to succeed in highly competitive environment. E-service quality can be described as overall customer evaluations and judgments regarding the excellence and the quality of eservice delivery in the virtual market place (Santos, 2003). Online shopping is a complex process that can be divided in to various sub-processes such as an investigation, searching for information, online transactions, or customer interactions. (Van. Riel et.al, 2001). Because of it is accessibility to compare product technical features and prices online than through traditional channels, e-service quality becomes a major aspects for customers (Santos, 11 2003). Online shopping sites are consequently directing their strategies towards increasing customer satisfaction and loyalty through improved service quality.

In this modern era of global competition two factors such as customer expectation and customer satisfaction vitally contributes towards the success of any industry. In case of a failure in meeting the expectation of customer will affect the overall growth and survival of the business in the market to withstand the global competition and market dynamism, it is essential for the business to scrutinize all the factors which leads to customer satisfaction in order to enable a business to point out the areas of weakness. Although the previous studies (Lee and Lin-2005, Zavarehetal.al2012, Yen and LU-2008, Collier and Bienstock-2006, Kassim and Abdullah-2010, Begam S2014, Chang et.al-2009) conducted on e-service quality and 


\section{International Journal of Engineering Applied Sciences and Technology, 2019 Vol. 4, Issue 5, ISSN No. 2455-2143, Pages 274-279 \\ Published Online September 2019 in IJEAST (http://www.ijeast.com)}

customer loyalty shows that there is only a less no of studies conducted on this particular subject in Kerala and there is no previous study conducted in Puthur Gramapanchayath, Thrissur. In this context, the present study conducted to find out the impact of e-service quality in online shopping on customer loyalty among Puthur Garmapanchayath, Thrissur.

\section{OBJECTIVES OF THE STUDY}

1. To explore the dimensions of e-service quality of online shopping in Puthur Gramapanchayath, Thrissur.

2. To identify the association between e-service quality dimensions with customer satisfaction and loyalty intension.

\section{RESEARCH METHODOLOGY}

The study is descriptive in nature as it describes the characteristics of a particular group with narration of facts concerning them. The association between variables are tested and studied to make the study exploratory also. Considering the location advantages and the time constraint, the present study has been confined to the Puthur Gramapanjayath in Thrissur, Kerala. A sample of 150 people selected on the basis of convenience sampling method. Data was collected from those who are available, have enough time and interest in filling the questionnaire so that the reliability is not affected. The study has been carried out with the help of both secondary and primary data. Primary data were collected with the help of structured questionnaire including two parts where first part relating to demographic data of the respondents which include age, gender, educational qualification etc. and second part includes the service quality constraints like efficiency, system availability, privacy\& security etc. For analysing the collected data SPSS were used with mathematical tools like percentages, averages etc. The study used a five point scale which anchors at 1(i.e. strongly disagree) and 5 (i.e. strongly agree). Scale development was on a review of relevant literature. Efficiency, system availability, privacy and responsiveness play a key role in building service quality. There for service quality was measured using these 4 constraints on a five point Likert scale. And for measuring overall service quality, customer satisfaction and loyalty intentions of the customers 'one most suitable indicator was used.

\section{REVIEW OF LITERATURE}

Research over the past decades has establish that service quality influences consumption decisions, and recently these findings have been applied to ecommerce. This chapter deals with the review of different studies and researches which directly or indirectly relate to the topic under study.

Begam S (2014) analysed that the effect of service quality on policy holders satisfaction in Salem division of Tamil Nadu. The Salem Division consists of 18 branches. Since the number of policy holders in each branch was large, the policyholders could not be selected on a proportional basis, a sample of 360 police holders, 20 from each branch Where are selected on the basis of convenience sampling method. The study reveals that the policyholders have low level of satisfaction with the basic amenities, service qualities, ease of procedure, company client relationship and technology. The study indicates that there is a strong relationship between the service quality and policyholder's satisfaction and service quality is a strong predictor of customer satisfaction Zavareh.et.al. (2012) conducted a study to construct e-service quality (e-SQ) for internet banking services in USA, Hong Kong, Taiwan, Sweden and UK and in addition, it attempted to examine the effect of e-SQ on e-customer satisfaction (e-CS) based on the primary data gathered from 392 internet banking users. The regression analysis performed to show the positive effect of e-SQ dimensions on e-CS and the findings indicate that the efficiency, reliability, trust, contact, an ease of use constitute e-SQ for internet banking services and there is a positive relationship exists between e-SQ an e- CS in internet banking. Ghane.et.al (2011) empirically investigates the impacts of e-satisfaction, e-trust, and eservice quality on e-loyalty, in e-banking as an aspect of B2C e-commerce context. Data was collected to test the model from faculties and students of Tehran universities as respondents, and empirical analyses were performed using SEM. The results point out that although service quality, esatisfaction, and e-trust have strong direct effect on e-loyalty, impacts of indirect effects with esatisfaction and e-trusts are more significant. And also it serves as a framework that indicates the full relationship among the three factors and their direct and indirect effects on e- loyalty. Sheng and Liu (2010) conducted an empirical study on effects of e-service quality on online customer satisfaction and loyalty by developing a new conceptual model of customer satisfaction and loyalty in online purchase. Where four dimensions of e-service quality- efficiency, requirement, fulfilment, system availability and privacy- are the four predictors from parasuraman's E-QUAL. A sample of 164 online buyers from a range of backgrounds was selected and a partial least square algorithm was then applies to analyse the data. The analytical results suggest that efficiency and fulfilment have positive cause on customer satisfaction and fulfilment and privacy have positive effect on 
either customer satisfaction or customer loyalty. And also loyalty is positively affected b customer satisfaction. Kassim and Abdullah (2010) conducted a cross cultural analysis among two cultures - Malaysian and Qatari to empirically investigate the relationship between perceived service quality, satisfaction, trust, and loyalty in ecommerce settings. A questionnaire was designed to measure service quality, to evaluate the customers 'satisfaction and trust using a convenience sampling technique to collect data from Malaysia and Qatar. Structural equation modelling (SEM) and general linear model of univariate analysis of variance analyses were used to establish the causal relations between the constructs. And the results found that Perceived service quality have a significant impact on customer satisfaction besides customer satisfaction was found to have a significant effect on trust. Also both customer satisfaction and trust have significant effects on loyalty through word of mouth (WOM). Yen and Lu (2008) conducted an empirical study to produce an expectancy disconfirmation theory (EDT) to explore e-service quality and the factors affecting an individual's loyalty intention towards online auctions. Data were collected from a total of 619 bidders in online auctions and a structural equation modelling (SEM) is used to assess the relationships of the research model. From that study they investigated that eservice quality measurements including efficiency, privacy protection, contact, fulfilment, and responsiveness have statistically significant influences on buyer's disconfirmation and also buyers' disconfirmation of online auction sale is positively connected with their satisfaction, and their satisfaction is positively correlate with loyalty intentions.

\section{RESULTS AND DISCUSSION}

This study is attempted to determine the dimensions of service quality and their effect on customer satisfaction and customer loyalty.

\subsection{Demographic profiles of respondents}

Table 1 shows the demographic profile of online shoppers in puthur gramapanjayath, Thrissur

Table 1 Demographic Profile of Respondents

\begin{tabular}{|c|c|c|}
\hline Demographic factors & Frequency & Valid percent \\
\hline Age & 9 & 9 \\
\hline Below 20 & 88 & 58.7 \\
\hline $20-30$ & 36 & 24 \\
\hline $30-40$ & 16 & 10.7 \\
\hline $40-50$ & 1 & 0.7 \\
\hline Above 50 & $\mathbf{1 5 0}$ & $\mathbf{1 0 0}$ \\
\hline Total & & 54 \\
\hline Male & 81 & 46 \\
\hline Fender & 69 & $\mathbf{1 0 0}$ \\
\hline Total & $\mathbf{1 5 0}$ & 31.1 \\
\hline Student & & 41.3 \\
\hline Occupation & 47 & 6 \\
\hline Employee & 62 & 13.3 \\
\hline Business & 9 & 8 \\
\hline Profession & 20 & $\mathbf{1 0 0}$ \\
\hline Others & 12 & 4.7 \\
\hline Total & $\mathbf{1 5 0}$ & 22 \\
\hline Educational Qualification & & 59.3 \\
\hline Matriculation & 7 & 14 \\
\hline Plus Two & 33 & $\mathbf{1 0 0}$ \\
\hline Under Graduation & 89 & 21 \\
\hline Post-Graduation & $\mathbf{1 5 0}$ & \\
\hline Total & & \\
\hline
\end{tabular}

(Source: Primary Survey)

Interpretation

The above table show that $58.7 \%$ respondents are belongs to 20-30 years of age category. That means, most of the online shoppers are youngsters. 54\% of the sample customers are male. Two major occupation categories in the sample are regular employees $(41.3 \%)$ and students 


\section{International Journal of Engineering Applied Sciences and Technology, 2019 \\ Vol. 4, Issue 5, ISSN No. 2455-2143, Pages 274-279 \\ Published Online September 2019 in IJEAST (http://www.ijeast.com)}

$(31.3 \%)$. Most of the respondents are under graduates $(59.3 \%)$.

\subsection{Descriptive statistics}

Mean and standard deviation of the variables are used to measure the overall service quality of online shopping sites from different dimensions. Dimensions with highest mean value and lowest standard deviation are considered as the dimension providing more service quality.

Table 5.2 Descriptive Statistics

\begin{tabular}{|c|c|c|c|}
\hline Dimension & Variable & Mean & Std. Deviation \\
\hline \multirow{5}{*}{ Efficiency } & $\begin{array}{l}\text { Information given in this online shopping site is } \\
\text { relevant }\end{array}$ & 3.59 & 1.057 \\
\hline & This online shopping site is well organized & 3.85 & 0.979 \\
\hline & This online shopping site is simple to use & 4.18 & 0.868 \\
\hline & $\begin{array}{l}\text { This online shopping site enables me to complete a } \\
\text { transaction quickly }\end{array}$ & 3.93 & 0.825 \\
\hline & Overall mean of efficiency & $\mathbf{3 . 8 8 7 5}$ & $\mathbf{0 . 9 3 2 2 5}$ \\
\hline \multirow{5}{*}{ System availability } & This online site is always available & 4.02 & 1.058 \\
\hline & This online site launches and runs right away & 3.55 & 0.952 \\
\hline & This online site does not crash & 2.89 & 1.037 \\
\hline & $\begin{array}{l}\text { Pages at this online site do not freeze after I enter } \\
\text { my buying information }\end{array}$ & 2.87 & 1.151 \\
\hline & Overall mean of system availability & $\mathbf{3 . 3 3 2 5}$ & $\mathbf{1 . 0 4 9 5}$ \\
\hline \multirow{5}{*}{ Privacy \& security } & This online site has adequate security features & 3.55 & 0.864 \\
\hline & $\begin{array}{l}\text { This online site does not share my personal } \\
\text { information with other sites }\end{array}$ & 3.55 & 0.872 \\
\hline & $\begin{array}{l}\text { This online site protects my personal information } \\
\text { from unauthorized access }\end{array}$ & 3.53 & 0.981 \\
\hline & $\begin{array}{l}\text { This online site protects information about my } \\
\text { transaction }\end{array}$ & 3.62 & 0.857 \\
\hline & Overall mean of privacy \& security & 3.5625 & $\mathbf{0 . 8 9 3 5}$ \\
\hline \multirow{5}{*}{ Responsiveness } & The seller offers promptness of reaction to requests & 3.47 & 0.895 \\
\hline & $\begin{array}{l}\text { Seller tells me, what to do if my transaction is not } \\
\text { processed? }\end{array}$ & 3.33 & 0.981 \\
\hline & $\begin{array}{l}\text { After I receive the product, the seller handles } \\
\text { product returns well }\end{array}$ & 2.97 & 1.212 \\
\hline & This online site takes care of problems promptly & 2.95 & 1.186 \\
\hline & Overall mean of responsiveness & 3.18 & $\mathbf{1 . 0 6 8 5}$ \\
\hline \multicolumn{2}{|c|}{ Overall mean of the Four dimensions } & 3.4906 & 0.9859 \\
\hline
\end{tabular}

(Source: Primary Survey)

Interpretation

The data shows that the variables like simple to use, availability, complete transaction quickly and well organized site has very high mean value; i.e. 4.18,4.02, 3.93, 3.85 respectively. So these variables provide more service quality to the customers of online shopping. Followed by them protect information about transactions, relevant site, protect personal information, adequate security features and runs right away has mean values $3.62,3.59,3.55,3.55,3.55$ respectively. The data also reveals that variables like reaction to requests, product return, promptness of problem caring, does not crash etc. has less mean value $(3.47,2.97,2.95$, and 2.89) as compared with other variables. So these variables provide less service quality to the online customers.

Overall mean of dimensions shows that efficiency has the highest mean value of 3.8875 , with a standard deviation of 0.93225 , thus it is evident that the efficiency provides more service quality in online shopping in puthur Garmapanchayat. Privacy and security is the next dimension that provides more service quality with a mean of 3.562. Responsiveness provides least service quality with mean value of 3.18 and standard deviation of 1.0685 . 


\section{International Journal of Engineering Applied Sciences and Technology, 2019 Vol. 4, Issue 5, ISSN No. 2455-2143, Pages 274-279 \\ Published Online September 2019 in IJEAST (http://www.ijeast.com)}

\section{FINDINGS OF THE STUDY}

1. Majority of the respondents are belongs to the age category of $20-30$ years $(58.7 \%)$ and most of the customers are males (54\%)

2. $59.3 \%$ of the respondents are qualified at under graduate level and Majority of the buyers are $(41.3 \%)$ employees.

3. Variables like simple to use, availability, complete transaction quickly and well organized site has very high mean value which provide more service quality to the customers of online shopping.

4. variables like reaction to requests, product return, promptness of problem caring, does not crash etc. has less mean value as compared with other variables so these variable provide a less level of service quality to online buyers.

5. Efficiency has the highest mean value of 3.8875 , with a standard deviation of 0.93225 , evident that the efficiency provides more service quality in online shopping.

6. Responsiveness provides least service quality with mean value of 3.18 and standard deviation of 1.0685 .

\section{CONCLUSION}

Service quality and customer satisfaction and loyalty go hand in hand and quality in service delivery is the key to succeed in today's highly competitive environment. In this study the researcher attempted to develop and empirically test a conceptual framework for how customers judge e-service quality and to analyse the effects of factors of e-service quality on customer loyalty in online shopping. For that purpose both primary and secondary data were used. Primary data was collected from a sample of 150 people in Puthur Garmapanchayat, Thrissur on the basis of convenience sampling method with the help of structured questionnaire. The researcher identified efficiency, system availability, privacy and security and responsiveness as the key dimensions of eservice quality by conducting a factor analysis and for exploring the e-service dimensions a descriptive analysis were used. In order to identify the association between eservice quality dimensions with customer satisfaction and customer loyalty regression analysis were also used by using SPSS. From the analysis it seems that majority of the respondents are male and youngsters who using the online websites for buying and they are well educated. And more than half of the customers prefer to buy fashion accessories from Flip kart and Amazon more. From the descriptive statistics like mean and standard deviation, it's clear that efficiency of the website is provide more service quality to online customers and responsiveness provide a least service quality.

Although the study shows that e-service quality dimensions and customer satisfaction are the key drivers of customer loyalty the current study has some limitations which offer leads for future research. First of all, this study measures service quality by using only four dimensions, so the future researchers may examine all the possible dimensions of e-service quality for enhancing its power in predicting customer satisfaction and customer loyalty. Second, the common method variance is a potential problem in analysing customer loyalty. Method biases and self-selection issue in questionnaire survey process is a methodological concern so it's possible to use other methodology for future research. Third, hence it's choose only a few online websites as a generalization for quality of online shopping it is possible to extend the number of websites for future research. And also this study chose online buyers as the research sample; it would be interesting for future research to extend the sample as online sellers too.

\section{REFERENCES}

1. Begam, S. (2014). "Service quality and its effect on policy holder's satisfaction in Insurance Sector (with special reference to LIC Salem division)", Indian Streams Research Journal, pp.1-7.

2. Brady, Michael.K and Cronin, John.C.J. (2001). "some thoughts on conceptualizing perceived service quality; A Hierarchical approach"”, The Journal of Marketing, pp.34-49.

3. Chang, Hsin.Hsin, Wang, Yao.Hua. And Yang, Wen.Ying. (2009). "the impact of e-service quality, customer satisfaction and loyalty on e-marketing: Moderating effect of perceived valuell", Total Quality Management, pp.423-443.

4. Collier, Joel.E and Bienstock, Carol.C. (2006). "Measuring service quality in eretailing", Journal of service research, pp. 260-275.

5. Cristobal, Eduard, Flavian, Carlos and Guinaliu, Miguel. (2007). "Perceived eservice quality (PeSQ) Measurement validation and effects on consumer satisfaction and web site loyalty", managing service quality: An international journal, pp.317-340.

6. Donio, Jean, Massari, Paola and Passiante, Giuseppina. (2006). "Customer satisfaction and loyalty in a digital environment: An empirical test", Journal of Consumer Marketing, pp.445-457. 
7. Ghane, Soheila, Fathian, Mohammad, and Gholamian, Mohammad.R. (2011). "Full relationship among e-satisfaction, e-trust, e-service quality, and e-loyalty: The case of Iran e-banking", Journal of Theoretical and Applied Information Technology, pp.1-6.

8. Gronroos, Christian. (1984). "A service quality model and its marketing implications", European Journal of marketing, pp.36-44.

9. Harris, Lloyd.C and Goode, Mark.M.H. (2004). "The four level of loyalty and the pivotal role of trust: A study of online service dynamics", Journal of Retailing, pp.139-158.

10. Kassim, Norizan and Abdullah, Nor.Asiah. (2010). "The effect of perceived service quality dimensions on customer satisfaction, trust, and loyalty in e-commerce settings: A cross cultural analysis", Asia pacific journal of marketing and logistics, pp.351-371.

11. Sheng, Tianxiang and Liu, Chunlin. (2010). "An empirical study on the effect of e-service quality on online customer satisfaction and loyalty", Nankai Business Review International, pp.273-283.

12. Yen, Chia.Hui and Lu, Hsi.Peng. (2008). "Effects of e-service quality on loyalty intension: an Empirical study in online auction", Managing Service Quality: An International Journa, pp.127-146.

13. Zavareh, Farnaz.Beheshti, Ariff, Mohd.Shoki.Bin.Md, Jusoh, Ahmad, Zakuan, Norhayati,Bahari, Ahamad. Zaidi and Ashourian, Mohsen. (2012). "Service quality dimensions and their effect on ecustomer satisfaction in internet banking services", Procedia Social and Behavioral Sciences, pp.441-445. 